\title{
Experimental Investigation of Pressure Drop \& Heat Transfer Coefficient for Aluminium Metal Foams
}

\author{
Meerapur Pankaj ${ }^{1}$, Anandkumar.S.Malipatil ${ }^{2}$ \\ ${ }^{1}$ (Department of Thermal Power Engineering, VTU,RO/PG Kalaburagi, India) \\ ${ }^{2}$ (Department of Thermal Power Engineering, VTU,RO/PG Kalaburagi, India)
}

\begin{abstract}
Metal foams are the new class of materials with their novel properties like high surface area to volume ratio, high strength to weight ratio and other thermal, mechanical and electrical properties. This study aims at investigating experimentally the pressure drop and heat transfers characteristics of four different aluminium open-cell foams namely 5, 10, 20 \& 40 pores per inch (PPI) so that the generated data could be useful for the design of compact heat exchangers. Metal foams are integrated in the test module consisting of machined aluminium rectangular box with a size of $100 \mathrm{~mm} \times 100 \mathrm{~mm} \times 10 \mathrm{~mm}$. Air is selected as working fluid. The experiments are conducted to measure the pressure drop across metal foam and heat transfer coefficient with the mass flow rate varying from 0.002 to $.011 \mathrm{~kg} / \mathrm{s}$. Parameters like permeability $(K)$ and !inertia coefficient (f) are used to characterise the flow through metal foams, as these are strongly dependent on foam geometry and foam size. Experimental results indicates for constant PPI of foam, pressure drop increasesl with the increases in mass flow rate and also pressure drop increases with increasing PPI. For a given PPI of foam, heat transfer coefficient increases with increase in mass flows rates and increase in PPI. The pressure drops and heat transfer coefficient derived from the experimental results serve as a useful data for the design of compact heat exchangers for aircraft applications.
\end{abstract}

Keywords: Surface area to volume ratio, High strength to weight ratio, Pressure drop, Heat transfer coefficient, permeability $(K)$, inertia coefficient $(f)$.

\section{Introduction}

Metal foams are new form of materials that show separate engaging qualities when contrasted with their robust material counterparts. Metal foams are cell division structures comprising of a robust metal, holding an extensive volume portion for gas filled pores. Those pores could be fixed (closed-cell foam) alternately they cam wood manifestation an interconnected system (open-cell foam). The pores in the open cell allow the passage of fluids while the closed cell configuration does not allow fluids to pass through it. The range of applications of open cell1metal foams are vast than those of closed cell. In our study we considered open cell metal foam. Those foams structure is a stochastic conveyance about interconnected pores. In the present aerospace sector, for any design, equipment compactness is desired without affecting its performance. Compact heat exchangers presently use fins with different geometries and shape to enhance the heat transfer. Metal foams with their high specific area can be used for enhancing heat transfer. This study is basically intended to study the pressure drop and thermal performance of metal foams. Later, results derived from this study will be used for comparison and design of compact heat exchangers for aerospace applications.

\section{Experimental Setup}

Experimental setup consists of settling chamber, air filter, control valve, orifice meter and duct assembly as shown in Figure below

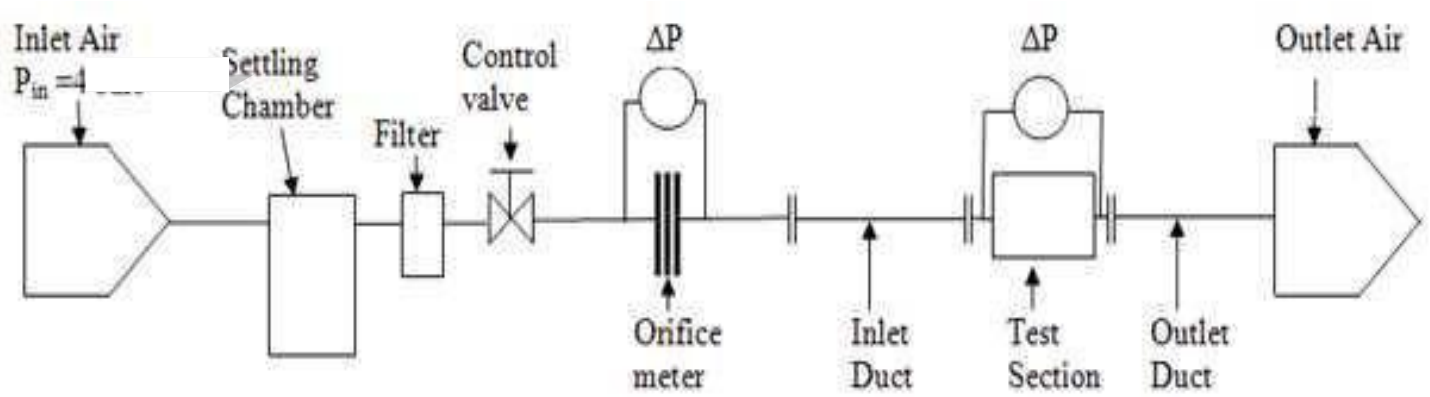

FIG 1. Experimental Setup 
Settling chamber was provided at the beginning which will absorb the pressure fluctuations in the main line and ensure continuous air supply at almost constant pressure. Air filter was provided after settling chamber to remove the any dirt particle from air which may disturb the flow or instruments. A control valve was provided in the line to fine controlling mass flow through ducts. An orifice meter was installed after regulating valve to measure the mass flow rate. Orifice meter was designed and from BS: 1045 standard. Duct assembly consists of inlet duct, test section \& outlet duct. Inlet \& outlet ducts were manufactured from $3 \mathrm{~mm}$ thick aluminium plates. The cross-section flow area of duct is rectangular $(100 \mathrm{~mm} \times 10 \mathrm{~mm})$. Flange type connections were made to inter connecting the ducts. These ducts were fastened by screw-nut arrangements. Asbestos gaskets were provided for sealing flanged joints. At the starting of inlet duct, flow straighter was provided for streamlining the flow. The length of inlet duct was $450 \mathrm{~mm}$ which will ensure the flow to be developed before entering the foam test section. Outlet duct was $250 \mathrm{~mm}$ long, which is meant to direct the flow and mounting instruments.

\section{Methodology}

Four metal foam samples of pore density 5, 10, 20 and 40 PPI (Pores per Inch) with verging on consistent porosity between $90 \%-92 \%$ were selected for the study. Those metal foams tests utilized within this test fill in were made toward ERG Materials aviation partnership and are made up of Duocel 6101-T6 aluminium alloy. Sizes of samples were $100 \mathrm{~mm}$ length, $100 \mathrm{~mm}$ width, and $10 \mathrm{~mm}$ height as shown in Fig.2. These metal foams were brazed to duct made up of same material as of metal foams as shown in Fig: 3 . Brazed metal foam ducts along with open metal foam samples were procured.

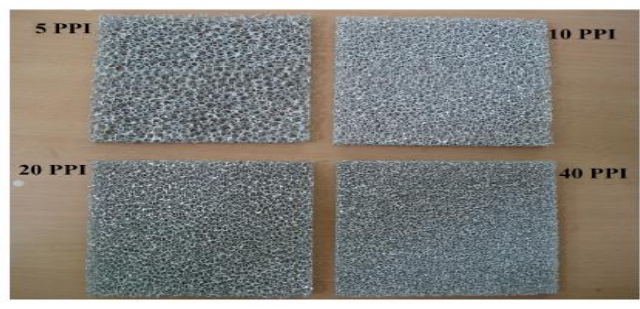

FIG 2. Metal Foam Samples

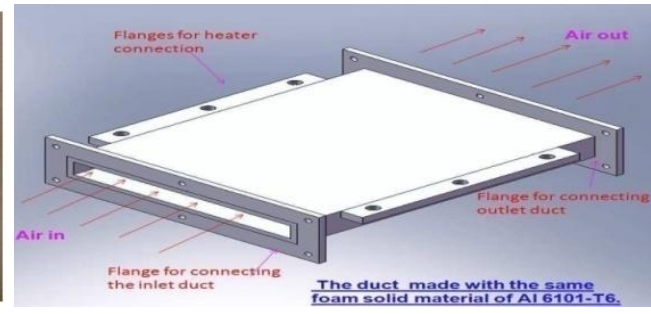

FIG 3. Duct Section

Following figure 5 show the Dimensions of metal foam brazed duct and Flange type connections were made to inter connecting the ducts. These ducts were fastened by screw-nut arrangements. Asbestos gaskets were provided for sealing flanged joints. At the starting of inlet duct, flow straighter was provided for streamlining the flow. The length of inlet duct was $450 \mathrm{~mm}$ which will ensure the flow to be developed before entering the foam test section. Outlet duct was $250 \mathrm{~mm}$ long as shows in fig 6.
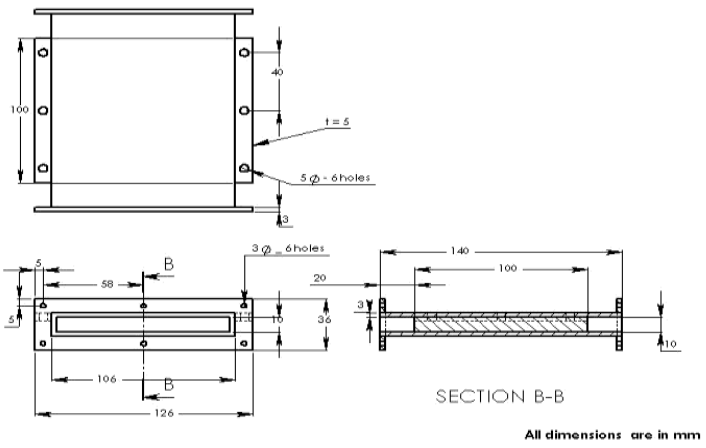

Fig:6. Inlet, outlet and metal foam duct arrangement
Fig: 5. Dimensions Duct

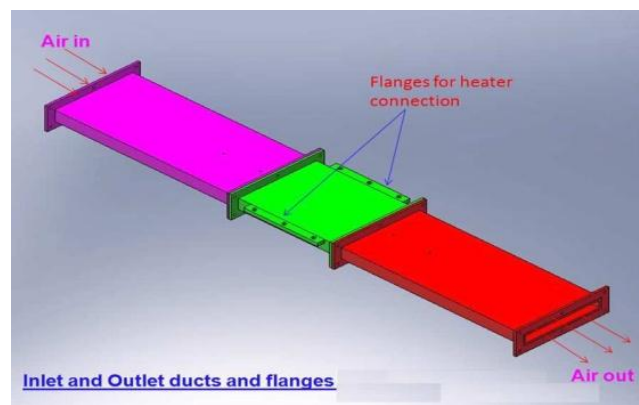

Two plate type electric resistance heaters were used to heat the metal foam from top and bottom side. Heater dimensions were $100 \mathrm{mmx} 100 \mathrm{~mm} \times 5 \mathrm{~mm}$. Heaters can give maximum heat flux of $2.8 \mathrm{~W} / \mathrm{cm}^{2}$. Heaters were placed on top and bottom of foam duct and held in the position by top and bottom heater covers. Holes were provided on heaters and heater covers for locating the thermocouples. Glass wool was insulated over heater covers to avoid the heat loss to the atmosphere. A heater controller was used to maintain the constant temperature condition on foam duct surface from outside. This includes the temperature indicator to set the desired temperature level. Ammeter and voltmeter were also incorporated to measure the heat input. 


\subsection{Instruments and Data Acquisition System} foam duct.

Following Fig.4 shows the locations of pressure probe and thermocouple locations across the metal

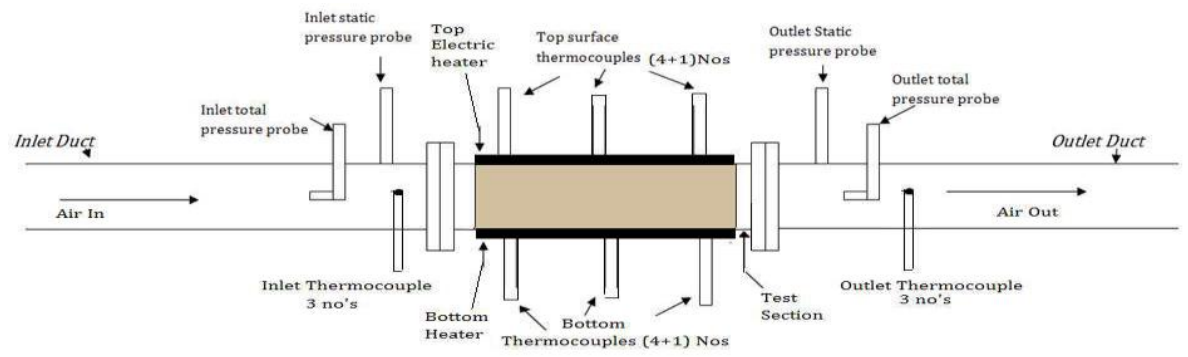

Fig 4. Pressure probes and thermocouple locations across metal foam duct

\subsection{Pressure Measuring System:}

Pressure readings were recorded in the locations and also as shown in Fig 4.

1. Pressure drop was measured across the orifice meter to measure the mass flow rate. Two pressure tapings were made on either side of orifice plate as per the standard. These pressures were measured through net scanner.

2. 2. Pressure drop across test section was measured by six static pressure ports. Three pressure ports on upstream side and other three were on downstream. Among upstream pressure ports one is positioned on top and remaining two on side faces of inlet duct. The average of these three will give the accurate pressure measurement. Similarly three pressure ports were positioned one on top \& two on side faces of outlet duct.

3. Two total pressure ports are provided on upstream and downstream test section to measure the inlet and outlet velocity to \& from the foam.

All the static and total pressure ports were connected to the Net Scanner (Model no: 9116) scanner is a Pneumatic Intelligent Pressure Scanner, with integral pressure transducers and a pneumatic calibration manifold.

\subsection{Temperature Measuring System:}

Temperature readings were recorded in the locations and as shown in Fig 4.

1. Inlet air temperature to the foam was measured by three thermocouples. One was located on top side and other two on side faces of duct.

2. Outlet air temperature from foam was measured from three thermocouples.

3. One was located on top side and other two on side faces of duct.

4. Top and bottom surface temperatures were measured by ten thermocouples located five on top and five on bottom side as shown in Fig.4.

Constantly on thermocouples was K-type for chromel-alumel build material, Hosting. Temperature range form $-200^{\circ} \mathrm{C}$ to $1250^{\circ} \mathrm{C}$. Yield starting with thermocouples were associated with those fluke information securing frame work (Model 2680A).

\section{Figures and Tables}

Manufacturer of metal foams has only given the range of porosities, but has not given actual porosities. So for the entire test samples actual porosity was calculated as shown below.

$\varepsilon=1-\rho(\mathrm{rel})=1-\frac{\rho f}{\rho s}$

Calculated actual porosities for all the samples were as shown in Table.1

\begin{tabular}{|c|c|c|c|c|c|c|c|c|c|}
\hline $\begin{array}{l}\text { SI } \\
\text { No }\end{array}$ & $\begin{array}{l}\text { Foam } \\
\text { Type }\end{array}$ & $\begin{array}{l}\text { Weight } \\
\text { of } \\
\text { foam } \\
\text { (M) }\end{array}$ & $\begin{array}{l}\text { Metal } \\
\text { foam } \\
\text { dimension } \\
\mathrm{s}\end{array}$ & $\begin{array}{l}\text { Volume } \\
\text { of foam } \\
\text { (V) }\end{array}$ & $\begin{array}{l}\text { Densit } \\
\text { y of } \\
\text { foam( } \\
\rho f)\end{array}$ & $\begin{array}{l}\text { Densit } \\
y \quad \text { of } \\
\text { Duocel } \\
\left(\rho_{s}\right)\end{array}$ & $\begin{array}{l}\text { Relative } \\
\text { density( } \\
\text { (rel) }\end{array}$ & $\begin{array}{l}\text { Porosity } \\
(\varepsilon)\end{array}$ & $\begin{array}{l}\text { Specific } \\
\text { surface area } \\
\text { (From ERG } \\
\text { Graph) }\end{array}$ \\
\hline & PPI & In kg & In $\mathrm{mm}$ & $\mathrm{In} \mathrm{m}^{3}$ & $\begin{array}{l}\mathrm{In} \\
\mathrm{kg} / \mathrm{m}^{3}\end{array}$ & $\begin{array}{l}\text { In } \\
\mathrm{kg} / \mathrm{m}^{3}\end{array}$ & - & $\%$ & $\mathrm{~m}^{2} / \mathrm{m}^{3}$ \\
\hline 1 & 5 & 0.024 & $\begin{array}{l}100.5 \mathrm{x} \\
100.4 \times 10\end{array}$ & $\begin{array}{l}1.009 \mathrm{E}- \\
04\end{array}$ & 237.85 & 2700 & 0.088 & 91.191 & 350.394 \\
\hline 2 & 10 & 0.024 & $\begin{array}{l}100.5 \mathrm{x} \\
100.5 \times 10\end{array}$ & $\begin{array}{l}1.010 \mathrm{E}- \\
04\end{array}$ & 237.62 & 2700 & 0.088 & 91.199 & 812.008 \\
\hline 3 & 20 & 0.022 & $\begin{array}{l}100.5 \mathrm{x} \\
100.6 \times 10\end{array}$ & $\begin{array}{l}1.011 \mathrm{E}- \\
04\end{array}$ & 217.60 & 2700 & 0.081 & 91.941 & 1187.008 \\
\hline 4 & 40 & 0.025 & $\begin{array}{l}100.2 \mathrm{x} \\
100.4 \times 10\end{array}$ & $\begin{array}{l}1.006 \mathrm{E}- \\
04\end{array}$ & 248.51 & 2700 & 0.092 & 90.796 & 1606.299 \\
\hline
\end{tabular}

Table 1. Metal foam porosities and specific surface area for all the samples. 


\subsection{Result and Discussion}

\subsubsection{Pressure Drop Experimental Procedure:}

In this experiment air will be at atmospheric temperature. For particular foam mass flow is set by regulating control valve. For every set mass flow rate following readings were taken.

1. Mass flow rate is calculated from following equation $(\mathrm{m})$ :

$\mathrm{m}=0.02956 \sqrt{\text { (Pupstream + Patm) } \Delta \mathrm{P}}$

2. Velocity is this is calculated from following equation

$$
\nu=\frac{\mathrm{m}}{p^{*} A C S}
$$

3.Pressure drop across the foam duct $(\Delta \mathrm{P})$ this is calculated from following equation

$$
\Delta P=\text { Pstatic in }- \text { Pstatic out }
$$

4. Inlet and outlet air temperatures (Tair in and Tair out):

This is required to calculate the properties of air. This temperature is noted down from fluke in-turn which is connected to thermocouple located inlet and outlet of the foam section.

This above procedure was repeated for mass flow rate range 0.002 to $0.011 \mathrm{~kg} / \mathrm{s}$.

This same procedure followed for other metal foam samples.

\section{* Pressure Drop Results:}

Fig.5, 6, 7 and 8 shows the pressure drop per unit length against mass flow rate for 5, 10, 20 \& 40PPI metal foams at $30,50,70$ and $90^{\circ} \mathrm{C}$ temperature respectively. In Fig.5 it is observed that

$>$ For particular PPI of foam, pressure drop per unit length increases with mass flow rate. This is because with increase in velocity, shear stress will increase. This will lead to increase in pressure drop.

$>$ For particular mass flow rate, pressure drop per unit length increases with increases in PPI. This is because as the PPI increases specific surface area increases, hence more metal foam surface will be exposed to air within same volume. Increase in surface area increases the flow resistance so pressure drop increases.

Above results are also true for temperature 50, 70 and $90^{\circ} \mathrm{C}$ as shown in Fig.6, 7 and 8

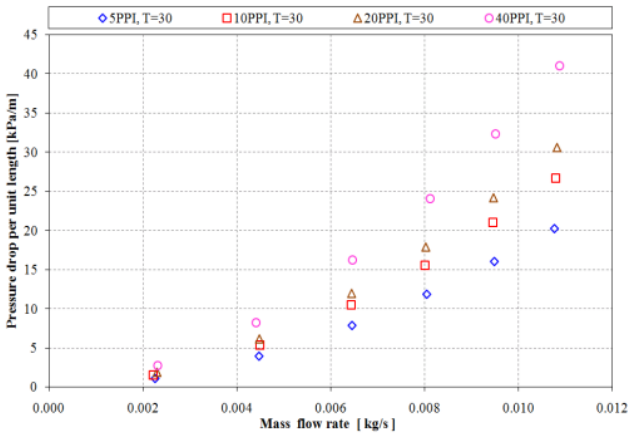

Fig 5. $\Delta \mathrm{P}$ v/s $\mathrm{m}$ at $\mathrm{T}=30^{\circ} \mathrm{C}$

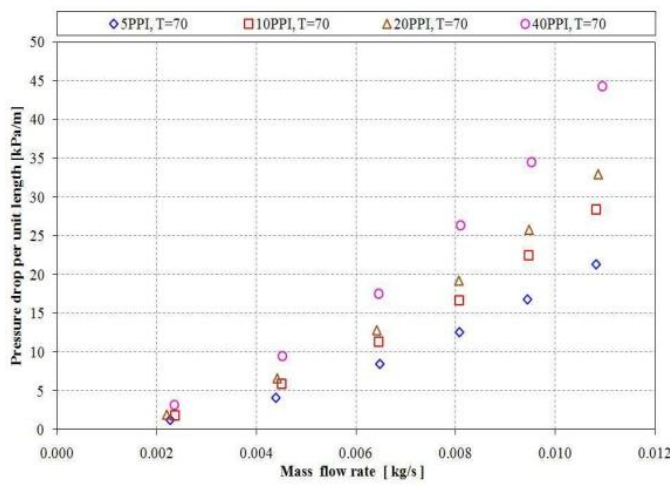

Fig 7. $\Delta \mathrm{P} v / \mathrm{s} \mathrm{m}$ at $\mathrm{T}=70^{\circ} \mathrm{C}$

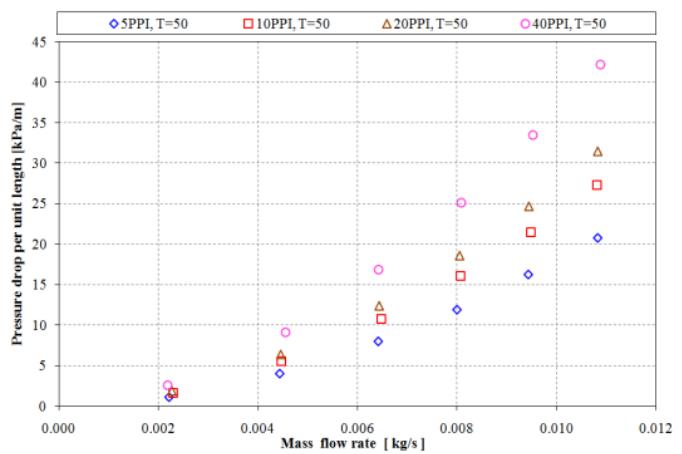

Fig 6. $\Delta \mathrm{P} v / \mathrm{s} \mathrm{m}$ at $\mathrm{T}=50^{\circ} \mathrm{C}$

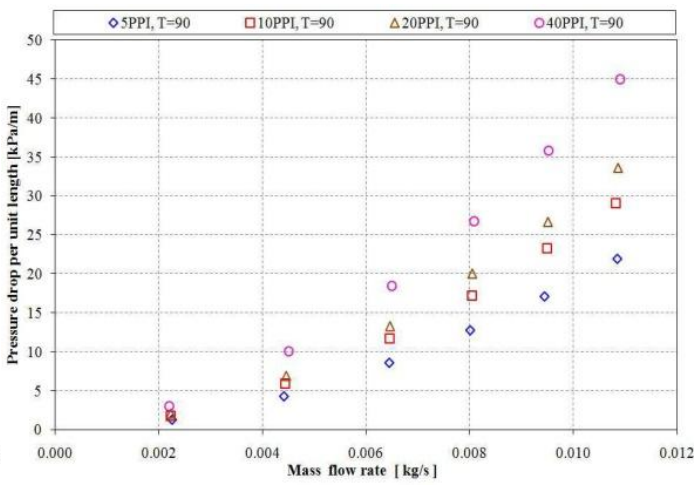

Fig 8. $\Delta \mathrm{P} v / \mathrm{s} \mathrm{m}$ at $\mathrm{T}=90^{\circ} \mathrm{C}$

\subsubsection{Heat Transfer Results:}

Heat transfer experiments to find heat transfer coefficient values for 5, 10, 20 and 40 PPI of metal foam sample in mass flow rate range of $.02 \mathrm{~kg} / \mathrm{s}$ to $.011 \mathrm{~kg} / \mathrm{s}$. Heat transfer coefficient is obtained by following formula. $\mathrm{h}=\frac{Q}{A * \Delta T}$ 
Where

Qout $=\mathrm{m}^{*} \mathrm{cp} *$ (Tair outlet - Tair inlet $)$

Fig 9 to 10 shows the effect of PPI on heat transfer coefficient. From these

figures following points can be observed.

$>$ For the particular PPI of foam, heat transfer coefficient increases with increase in mass flow rate.

$>$ For the particular mass flow rate heat transfer coefficient increases with increases in PPI. This is because, with increase in PPI specific surface area increases. Hence more surface area will be available for heat transfer and also with increase in PPI, pore density increases. Thus fluid has to pass through more tortuous path which makes better mixing and enhances the heat

transfer rate.

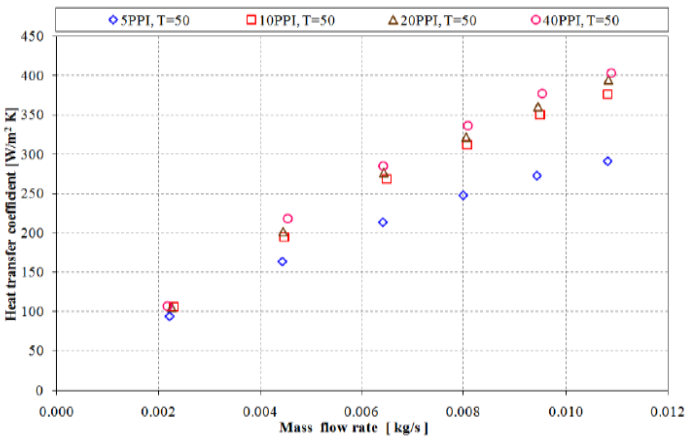

Fig 9. $\mathrm{h}$ v/s $\mathrm{m}$ at $\mathrm{T}=50^{\circ} \mathrm{C}$

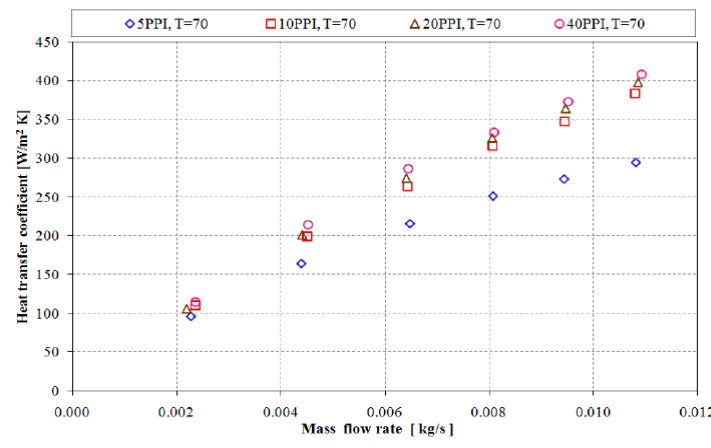

Fig10. $\mathrm{h}$ v/s $\mathrm{m}$ at $\mathrm{T}=70^{\circ} \mathrm{C}$

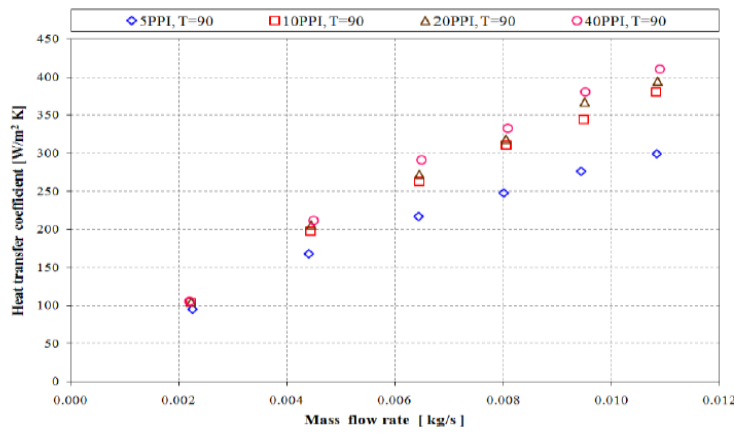

Fig10. h v/s m at $\mathrm{T}=90^{\circ} \mathrm{C}$

Following Fig 11 shows the friction factor against Reynolds number for all PPI of foam with dissimilar temperatures. From the graph it can be observe that, for constant Reynolds number friction factor Value for different temperatures will be same. So, for particular foam when friction factor is plotted against Reynolds number

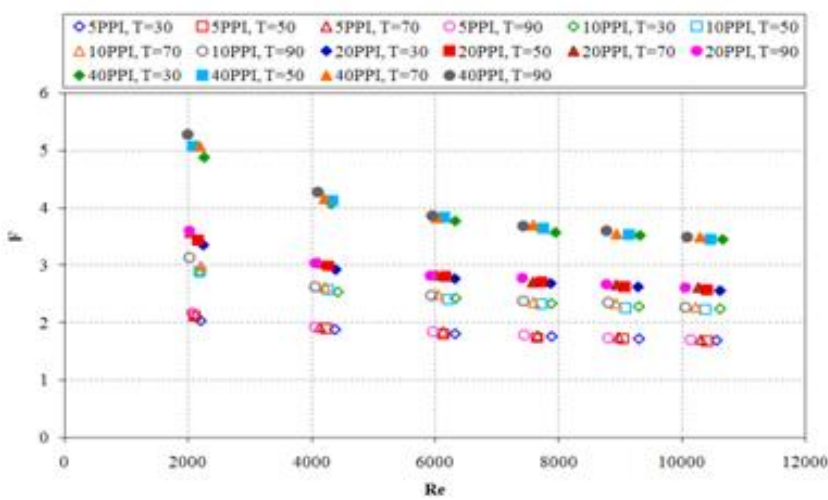

Fig 11. Friction factor against Reynolds number

Friction factor $(\mathrm{F})$ and Reynolds number $(\mathrm{Re})$ is calculated by from following respective equation given below. $\mathrm{F}=\frac{\Delta \mathrm{P}}{4 \frac{\mathrm{L}}{\mathrm{Dh}}, \frac{\mathrm{PV}}{2}}$
$\mathrm{Re}=\frac{\rho \mathrm{pDh}}{\mu}$ 


\section{Conclusion}

The experimental pressure drop and heat transfer study has been conducted on four open cell aluminium metal foam samples i.e. 5, 10, 20 and 40 PPI which were brazed to metal foam duct and have almost same porosity. Air was used as working fluid for study. Pressure drop and heat transfer experiments were conducted at different average metal foam duct temperatures namely $30,50,70$ and $90^{\circ} \mathrm{C}$. Pressure drop results show that, for particular PPI of foam pressure drop for every unit length increases with mass flow rate. For particular mass flow rate, pressure drop for each unit length increase with increase in PPI and for higher mass flow rate this increase in pressure drop with PPI is more than lower mass flow rates. The effect of average metal foam duct temperature on pressure drop per unit length is very less at lower mass flow rates, but at higher mass flow rates for a particular PPI of metal foam, pressure drop increases with increase in temperature. For all the PPI of metal foam increase in pressure drop is linear with respect to temperature. It can also be observed that, with increase in temperature, rate of increase of pressure drop increases with increase in PPI.

Heat transfer experiment results shows that, for particular PPI of foam, heat transfer coefficient increases with increase in mass flow rate and it is independent of temperature. For specific mass flow rate, heat exchange coefficient increments with increment in PPI. This expansion in heat exchange coefficient is more for 5 PPI to 10 PPI. At that point after increment in heat exchange coefficient from 10PPI to 20PPI and 20 PPI to 40 PPI is less.

\section{Journal Papers:}

\section{References}

[1]. Simone Mancin, Claudio Zilio, Alberto Cavallini, Luisa Rossetto, "Pressure drop during air flow in aluminum foams" International Journal of Heat and Mass Transfer 53 (2010) 3121-3130.

[2]. A.Bhattacharya, V.V. Calmidi, R.L. Mahajan, "Thermophysical properties of high porosity metal foams", Int. J. Heat Mass Transfer 45(2002) 1017-1031.

[3]. N. Dukhan, Correlations for the pressure drop for flow through metal foam, Exp. Fluids 41 (2006) 665-672.

[4]. K. Boomsma, D. Poulikakos, F. Zwick, Metal foams as compact high performance heat exchangers, Journal Of Mech. Master. 35 (2003) 1161-1176

[5]. Calmidi, V.V. and Mahajan, R.L., 2000, "Forced convection in High Porosity Metal Foams," Journal of Heat Transfer. Vol. 122, pp. 619-625.

[6]. J.F. Liu, W.T. Wu, W.C. chiu, W.H. Hsieh, Measurements and correlation of friction characteristic of flow Through foam matrixes, Exp. Therm. Fluid Sci. 30(2006) 329-336

[7]. Arun Muley, Carl Kiser, Bengt Sunen, Ramesh K Shah, seventh International conference on Enhanced, Compact and Ultra-Compact Heat Exchanger (2009).

[8]. A.M. Mahalle, Dr. B.N. Jajoo, "Convection Enhancement in a Channel using Porous Material" IE(I) Journal -MC Vol 88, October 2007.

[9]. Kim, S. Y., Peak, J. W. and Kang, B. H., 2000, "Flow and Heat Transfer Correlation for porous-Fin Heat Exchanger," Trans. of the ASME, 122, pp. 572-578.

[10]. Hwang, J. J., Hwang, G. J., Yeh, R. H. and Chao, C. H., 2002, "Measurements of Interstitial Convective Heat Transfer and Frictional Drag for Flow Across Metal Foams," ASME J. Heat and Mass Transfer, 124, pp. 120-129.

Books:

[1]. "Fluid Mechanics", Frank. M. White, Fourth edition, WCB McGraw-Hill Publications.

[2]. "Heat Transfer A Basic Approach", M. Nicati Ozisik, 1985 edition, McGraw-Hill Publication. 